\title{
Analisis SWOT peningkatan daya saing pada UKM keripik nangka di Kabupaten Malang
}

\author{
SWOT analysis of increasing competitiveness in SMEs of jackfruit chips \\ in Malang Regency
}

\author{
Cahyuni Novia $^{1)^{*}}$, Saiful $^{1)}$, Deny Utomo ${ }^{2 *}$ \\ ${ }^{1}$ Fakultas Teknik, Universitas Nurul Jadid, Probolinggo \\ ${ }^{2}$ Fakultas Pertanian, Universitas Yudharta, Pasuruan \\ *Email Korespondensi: vhie771108@gmail.com, denyut369@gmail.com
}

Informasi Artikel:

Dikirim: 10/07/2020; disetujui: 05/01/2021; diterbitkan: 30/03/2021

\begin{abstract}
Play an important role in the growth and stabilization of the Indonesian economy (SMEs). However, SMEs are not ready, because there is still low access to markets and a lack of reliable human resources (there are still many SMEs unable to categorize their strengths, weaknesses, opportunities and threats) so that they are unable to create strategies to develop their business. The purpose of this study was to analyze the strengths, weaknesses, opportunities and threats as well as to determine the strategy to increase the power of jackfruit chips SMEs in Malang Regency. The research location is in Malang Regency. Data collection obtained from 25 respondents who are owners of the jackfruit chips SMEs in Malang Regency. The technique of data analysis using the SWOT matrix determines the priority strategies for increasing the competitiveness of jackfruit chips in Malang Regency. The results showed that efforts to improve the competitiveness of the jackfruit chips SMEs in Malang Regency could be carried out with the following strategic priorities: the best strategies to use strength to take advantage of existing opportunities are; 1) increasing the quality of jackfruit chips according to SNI, because products that have advantages do not use preservatives, 2) expanding the location of jackfruit chips marketing by utilizing technological advances for product promotion so that sales increase, 3) improving employee skills by conducting training accompanied by related institutions (government and educational institutions), 4) increase the number of jackfruit chips production by determining the selling price according to the quality produced by innovating in each production process.
\end{abstract}

Keywords: competitiveness, SMEs jackfruit chips, SWOT

\begin{abstract}
ABSTRAK
Usaha kecil dan menengah (UKM) memainkan peran penting dalam pertumbuhan dan stabilisasi perekonomian Indonesia. Namun UKM tidak siap, karena masih rendahnya kemampuan akses ke pasar dan kurangnya sumber daya manusia yang dapat diandalkan (masih banyak UKM tidak mampu mengkategorikan kekuatan, kelemahan, peluang, dan ancaman) mempengaruhi UKM sehingga belum mampu menciptakan strategi untuk mengembangkan bisnisnya. Tujuan penelitian ini untuk menganalisis strengths, weaknesses, opportunities, dan threats serta menentukan strategi peningkatan daya saing UKM keripik nangka di Kabupaten Malang. Lokasi penelitian berada di daerah Kabupaten Malang. Pengumpulan data diperoleh dari 25 responden yang merupakan
\end{abstract}


pemilik UKM keripik nangka di Kabupaten Malang. Teknis analisis data menggunakan matriks SWOT kemudian menentukan prioritas strategi peningkatan daya saing UKM keripik nangka di Kabupaten Malang. Hasil penelitian menunjukkan bahwa upaya untuk meningkatkan daya saing UKM keripik nangka di Kabupaten Malang bisa dilakukan dengan beberapa prioritas strategi berikut ini: strategi terbaik untuk menggunakan kekuatan dalam memanfaatkan peluang yang ada adalah; 1) peningkatan kualitas keripik nangka sesuai SNI, karena produk sudah mempunyai kelebihan tidak menggunakan bahan pengawet, 2) memperluas lokasi pemasaran keripik nangka dengan memanfaatkan kemajuan teknologi untuk promosi produk agar penjualan meningkat , 3) meningkatkan keterampilan karyawan dengan melakukan pelatihan yang didampingi oleh lembaga terkait (pemerintah dan lembaga pendidikan), 4) meningkatkan jumlah produksi keripik nangka dengan menentukan harga jual yang sesuai dengan kualitas yang dihasilkan dengan melakukan inovasi di setiap proses produksi.

Kata Kunci: daya saing, UKM keripik nangka, SWOT

\section{PENDAHULUAN}

UKM berperan penting sebagai penggerak perekonomian, walaupun UKM hanya memiliki tenaga kerja, asset, dan omzet yang tergolong kecil, namun dengan jumlah yang besar membuat UKM ini menjadi penunjang bagi perekonomian (Hermanto et al., 2016). UKM juga memiliki peran penting dalam sektor pariwisata, yakni untuk mempekerjakan masyarakat yang berdomisili di sekitar daerah wisata sehingga dapat memetik keuntungan dari adanya sektor pariwisata tersebut. Kabupaten Malang merupakan salah satu wilayah di Jawa Timur yang menjadi salah satu tujuan pariwisata bagi wisatawan dalam negeri dan luar negeri. Sektor pariwisata di kabupaten Malang berkembang pesat setiap tahun. Hal ini menyebabkan tumbuhnya sektor-sektor lain yang menunjang pariwisata, yaitu industri pengolahan. Kabupaten Malang memiliki industri agro paling besar dibanding wilayah lainnya di Jawa Timur, dengan pangsa pasar dan produktivitas relatif tinggi (Prianto, 2011). Salah satu komoditas hasil pertanian yang dibuat olahan makanan khas sebagai oleh-oleh para wisatawan adalah nangka yang diolah menjadi keripik nangka. Buah nangka diolah menjadi keripik nangka memberikan nilai tambah terhadap buah nangka, sehingga memiliki nilai ekonomis yang lebih tinggi dan daya simpan lebih lama. Produksi buah nangka di Kabupaten Malang berdasarkan data Badan
Pusat Statistik Tahun 2015 sebesar 218.531 Kuintal/tahun (BPS, 2015). Menurut SNI-014269-1996, keripik nangka adalah makanan yang dibuat dari daging buah nangka (Artocarpus integra) masak, dipotong/disayat dan digoreng memakai minyak secara vakum dengan atau tanpa penambahan gula serta bahan tambahan makanan yang diizinkan (BSNI, 1996)

Industri pengolahan keripik nangka di Kabupaten Malang mayoritas dilakukan oleh UKM. Usaha kecil dan menengah (UKM). UKM mempunyai peran yang semakin penting dalam pertumbuhan ekonomi sebagian besar negara. Pentingnya UKM disadari begitu besar ketika melihat ketahanan ekonomi UKM yang begitu besar di beberapa belahan dunia (Purwidianti dan Rahayu, 2017). Meski kontribusinya kuat, UKM tetap ada rentan terhadap perubahan suasana ekonomi (Thamrin et al., 2017). Perkembangan industri keripik buah menuntut pelaku usaha untuk terus meningkatkan daya saing dari produk yang dihasilkannya di pasar global yang kompetitif. Produksi industri pengolahan nangka saat ini sebagian besar masih tergantung pada permintaan pasar. Banyaknya UKM yang bergerak dalam bidang yang sama dan memproduksi produk yang sama, mengharuskan UKM dapat bersaing agar usaha yang dijalankan bertahan lama. UKM keripik nangka yang masih aktif di Kabupaten Malang berdasarkan data dari Dinas Perdagangan dan Perindustrian di 
Kabupaten Malang Tahun 2017 sebanyak 25 UKM (Disperindag, 2017). Produksi keripik nangka rata-rata untuk satu UKM di Kabupaten Malang sebesar 15-20 kg/bulan. Pemasaran keripik nangka untuk saat ini tersebar di wilayah Kota Malang, Batu, Surabaya, Semarang dan Jakarta. Kendalakendala yang umumnya dihadapi oleh para pengusaha kecil menengah atau UKM yang mempengaruhi daya saing adalah: Produktivitas rendah, nilai tambah rendah, Jumlah investasi yang sangat kecil, Jangkauan pasar yang sempit, Jaringan usaha sangat terbatas, Akses ke sumber modal dan bahan baku terbatas, manajemen yang masih belum profesional dan sumber daya manusia pada umumnya belum memiliki kualitas bersaing untuk maju. Russell dan Millar (2014) menyatakan bahwa ada lima komponen competitive priority untuk meningkatkan daya saing UKM, yaitu; biaya, mutu, waktu, fleksibilitas, dan inovasi

UKM keripik nangka di Kabupaten Malang rata-rata sudah memiliki semua komponen tersebut tapi belum efektif dalam menggunakannya. Maka, harus lebih mengkaji lebih dalam lagi dimensi tersebut. Hasil penelitian terdahulu Hubeis et al. (2015) menunjukkan strategi untuk meningkatkan UKM berdaya saing dilakukan dengan: (1) Meningkatkan kerja sama untuk menjaga kontinuitas ketersediaan bahan baku antar daerah (2) membangun kawasan industri produk UKM (3) Meningkatkan peran pemerintah swasta dan perguruan tinggi/penelitian pengembangan.

Hasil penelitian mengenai kualitas keripik buah nangka dengan metode six sigma menunjukkan bahwa hasil evaluasi kualitas yang diperoleh oleh Sigma produksi sebesar 2,05. Faktor-faktor yang menyebabkan rusaknya keripik nangka adalah mesin, bahan, manusia, dan metode. Peningkatan prioritas dilakukan dengan mengatur ulang kecepatan putaran pemintal sesuai dengan standar, menyelesaikan prosedur operasional standar pemintal (SOP) dan memilih nangka yang tepat. Nangka dari Malang bisa menjadi bahan baku alternatif karena menghasilkan lebih banyak keripik nangka (Sucipto et al., 2018). Hasil penelitian mengenai identifikasi bahaya dan penentuan titik kendali kritis pada UKM keripik nangka di Jember menunjukkan Tahapan proses produksi keripik nangka dimulai dari mengupas dan mengiris buah nangka, pencucian daging buah nangka, pembekuan di dalam freezer, pendinginan suhu ruang, penggorengan, pengeringan, pengemasan dan penyimpanan. Dalam pembuatan keripik nangka yang dilakukan oleh UKM di Jember terdapat 2 jenis potensi bahaya yaitu dari segi fisik dan biologis. Berdasarkan hasil identifikasi terdapat 3 proses yang menjadi titik kritis yaitu proses pengupasan dan pengirisan buah nangka, proses pendinginan suhu ruang dan proses pengemasan. Penentuan titik kritis ini, UKM dapat membuat kontrol pada proses tersebut agar produk yang dihasilkan memiliki tingkat keamanan pangan yang baik (Setyoko, 2019).

Keunggulan kompetitif bisa diraih jika UKM memilih strategi bisnis yang tepat dengan terlebih dahulu melakukan strategi proses manajemen (Kraus et al, 2011). Implementasi dari manajemen strategis meningkatkan daya saing, mengurangi biaya, meningkatkan pengambilan keputusan, memfasilitasi implementasi sistem motivasi karyawan, mempersingkat waktu pengiriman, dan kualitas kepuasan pelanggan yang lebih tinggi (Holátová dan Monika, 2013). Analisis SWOT adalah alat manajemen strategis untuk mengidentifikasi sejauh mana strategi saat ini dari sebuah organisasi yang mampu menghadapi pengambilan perubahan tempat di lingkungan bisnis (Rangkuti, 2015). Implementasi dari manajemen strategis meningkatkan daya saing, mengurangi biaya, meningkatkan pengambilan keputusan, memfasilitasi implementasi sistem motivasi karyawan, mempersingkat waktu pengiriman, dan kualitas kepuasan pelanggan yang lebih tinggi (Holátová dan Monika, 2013). Tujuan dari penelitian ini adalah menganalisis dan menentukan strategi peningkatan daya saing 
UKM keripik nangka di kabupaten Malang berdasarkan hasil analisis SWOT.

\section{METODE}

Penelitian ini dilaksanakan di daerah Kabupaten Malang. Pengumpulan data diperoleh dari 25 responden yang merupakan pemilik UKM keripik nangka di Kabupaten Malang. Teknis analisis data menggunakan analisis SWOT dan diagram kartesius SWOT untuk menentukan strategi peningkatan daya saing UKM keripik nangka di Kabupaten Malang. Menurut Solihin (2012), analisis SWOT merupakan alat analisis yang bertahan paling lama serta banyak digunakan oleh perusahaan untuk melakukan analisis situasional dalam formulasi strategi.

Pengolahan dan analisis data terdiri dari analisis perumusan strategi. Perumusan dan implementasi strategi adalah salah satu tugas terpenting yang dilakukan para manajer organisasi (Gupta, 2015). UKM menghadapi banyak tantangan yang mempengaruhi pertumbuhan dan keberadaan mereka. Namun, mereka jarang mengadopsi manajemen strategis perencanaan seperti analisis SWOT yang mempertimbangkan lingkungan eksternal untuk peluang dan ancaman dan internal kondisi untuk kekuatan dan kelemahan (Thamrin et al, 2017).

\section{HASIL DAN PEMBAHASAN}

Analisis SWOT merupakan alat analisis yang bertahan paling lama serta banyak digunakan oleh perusahaan untuk melakukan analisis situasional dalam formulasi strategi (Solihin \& Ismail, 2012). Matrik SWOT adalah sebuah alat yang bisa digunakan untuk menyusun dan mengembangkan strategi. Faktor-faktor yang bisa digunakan untuk pengembangan strategi meliputi kekuatan (strength) kelemahan (weakness), peluang (opportunity), ancaman (treat). Kekuatan mengacu pada kemampuan yang melekat untuk bersaing dan tumbuh kuat. Kelemahan adalah kekurangan inheren yang menghalangi pertumbuhan dan kelangsungan hidup usaha. Kekuatan dan kelemahan terutama internal. Peluang adalah peluang bagus dan bukaan tersedia untuk pertumbuhan. Ancaman sangat luar biasa menggunakan tantangan, yang mungkin menekan kekuatan, memperburuk kelemahan dan menahan dengan adanya peluang dieksploitasi. Peluang dan ancaman bersifat lingkungan dan luar (Thamrin et al, 2017). Adapun strategi yang dibentuk melalui matrik SWOT bisa dilihat di tabel 1 di bawah ini.

Tabel 1. Matrik analisis SWOT

\begin{tabular}{|c|c|c|}
\hline & Kelemahan $(\mathbf{W})$ & Kekuatan (S) \\
\hline Internal & $\begin{array}{l}\text { 1. Kemampuan SDM masih } \\
\text { rendah } \\
\text { 2. Promosi produk berbasis } \\
\text { web tidak maksimal } \\
\text { 3. Wilayah distribusi terbatas } \\
\text { 4. Belum adanya arsip laporan } \\
\text { keuangan dengan baik } \\
\text { 5. Bahan baku bersifat } \\
\text { musiman dan tidak adanya } \\
\text { kontrak ke pemasok } \\
\text { 6. Akses ke lembaga keuangan } \\
\text { untuk pengembangan UKM } \\
\text { masih rendah }\end{array}$ & $\begin{array}{l}\text { 1. Memiliki produk yang } \\
\text { berkualitas } \\
\text { 2. UKM keripik nangka terus } \\
\text { melakukan inovasi produk } \\
\text { 3. Harga bersaing di pasar } \\
\text { 4. Tenaga kerja yang mudah } \\
\text { didapat } \\
\text { 5. Produk tanpa bahan } \\
\text { pengawet makanan } \\
\text { 6. Makanan khas oleh-oleh } \\
\text { dari Malang }\end{array}$ \\
\hline $\begin{array}{l}\text { 1. Pengembangan } \\
\text { wisata }\end{array}$ & $\begin{array}{lcr}\begin{array}{l}\text { Strategi } \\
\text { kelemahan }\end{array} & \text { untuk } & \text { (Mengatasi } \\
\text { peluang) }\end{array}$ & $\begin{array}{l}\text { Strategi S-O (Menggunakan } \\
\text { kekuatan untuk } \\
\text { memanfaatkan peluang) }\end{array}$ \\
\hline 2. Pertumbuhan ekonomi & 1. Memanfaatkan & 1. Peningkatan \\
\hline
\end{tabular}


semakin membaik

3. Kemajuan teknologi dan informasi

4. Kebijakan pemerintah yang UKM

5. Adanya pangsa pasar yang potensial

6. Permintaan yang semakin meningkat pada produk keripik nangka mendorong kemajuan

pelatihan dari pemerintah untuk meningkatkan keterampilan karyawan dan mengadakan pelatihan agar selalu siap dalam menghadapi kemajuan teknologi dan informasi

2. Memanfaatkan kemajuan teknologi dan informasi untuk promosi produk agar penjualan meningkat

3. Melakukan kerja sama dengan pemerintah dan lembaga terkait mengenai keterbatasan modal

4. Memperluas jaringan distribusi dengan melakukan kerja sama antar UKM dalam memasuki pasar baru untuk mendapatkan konsumen dengan memanfaatkan produk sebagai makanan khas daerah

\section{Ancaman (T)}

1. Harga bahan baku yang fluktuatif

2. Adanya pesaing baru dengan usaha sejenis

3. Konsumen sensitif terhadap harga

4. Produk baru sejenis yang lebih inovatif

5. Tidak melakukan pengemasan dengan baik

6. Kualitas bahan baku tidak sesuai dengan harapan

Strategi W-T (Mengatasi

kelemahan untuk

\section{mengantisipasi ancaman)}

1. Melakukan inovasi terhadap pengembangan produk yang mempunyai nilai tambah tinggi dengan harga yang kompetitif

2. Meminimalisasi tingkat kerugian akibat berubahnya harga dan kualitas bahan baku

3. Melakukan kontrol terhadap proses produksi dan pengemasan

4. Melakukan kegiatan pencatatan keuangan agar mempunyai arsip laporan keuangan keripik nangka sesuai SNI

2. Memperluas lokasi pemasaran keripik nangka

3. Meningkatkan motivasi dan keterampilan karyawan

4. Meningkatkan jumlah produksi keripik nangka

\section{Strategi S-T (Menggunakan kekuatan untuk mengatasi Ancaman)}

1. Melakukan peningkatan kualitas produk dengan perawatan mesin secara berkala

2. melakukan inovasi produk agar dapat bertahan dengan persaingan yang kompetitif

3. Meningkatkan kualitas kemasan agar lebih menarik

4. Memenuhi persyaratan yang berlaku baik izin maupun kemasan untuk produk makanan

5. Melakukan kerja sama dengan pemasok bahan baku agar selalu stabil baik dalam kualitas maupun kuantitas.
Setiap organisasi berusaha menetapkan strategi untuk perkembangan dan pertumbuhannya dan yang harus dilakukan hal ini, harus memperhitungkan faktor-faktor yang mempengaruhi keberhasilan atau kegagalannya (Abdel-Basset et al, 2018) UKM jarang sekali menggunakan alat analisis SWOT, namun UKM menyadari banyak faktor dalam area fungsional spesifik yang memengaruhi upaya mereka untuk 
mencapai tujuan bisnis (Wiid, Cant, dan Holtzhausen, 2015). Faktor-faktor tersebut dapat diidentifikasi dalam analisis SWOT. Analisis SWOT adalah alat yang digunakan untuk perencanaan strategis dan manajemen strategis dalam organisasi. Dapat digunakan secara efektif untuk membangun strategi organisasi dan strategi kompetitif (Gürel dan Tat, 2017).

Rumusan strategi yang diperoleh dari analisis SWOT di atas merupakan rumusan strategi yang bertujuan untuk memanfaatkan kekuatan dan peluang serta meminimalkan kelemahan dan ancaman, di mana dalam implementasinya harus melibatkan masyarakat, pelaku usaha, pemerintah dan pihak-pihak terkait lainnya. Dengan strategi tersebut, diharapkan pemerintah dan UKM sebagai pelaku usaha memiliki kewenangan masing-masing dalam meningkatkan daya saing UKM keripik nangka di Kabupaten Malang.

1. Strategi SO (Menggunakan kekuatan dalam memanfaatkan peluang)

a. Peningkatan kualitas keripik nangka sesuai SNI,

b. Memperluas lokasi pemasaran keripik nangka,

c. Meningkatkan keterampilan karyawan,

d. Meningkatkan jumlah produksi keripik nangka.

2. Strategi W-O (Mengatasi kelemahan untuk meraih peluang)

a. Memanfaatkan program pelatihan dari pemerintah untuk meningkatkan keterampilan karyawan dan mengadakan pelatihan agar selalu siap dalam menghadapi kemajuan teknologi dan informasi

b. Memanfaatkan kemajuan teknologi dan informasi untuk promosi produk agar penjualan meningkat

c. Melakukan kerja sama dengan pemerintah dan lembaga terkait mengenai keterbatasan modal

d. Memperluas jaringan distribusi dengan melakukan kerja sama antar UKM dalam memasuki pasar baru untuk mendapatkan konsumen dengan memanfaatkan produk sebagai makanan khas daerah

3. Strategi S-T (Menggunakan kekuatan untuk mengatasi Ancaman)

a. Melakukan peningkatan kualitas produk dengan perawatan mesin secara berkala

b. Melakukan inovasi produk agar dapat bertahan dengan persaingan yang kompetitif

c. Meningkatkan kualitas kemasan agar lebih menarik

d. Memenuhi persyaratan yang berlaku baik izin maupun kemasan untuk produk makanan

e. Melakukan kerja sama dengan pemasok bahan baku agar selalu stabil baik dalam kualitas maupun kuantitas

4. Strategi W-T (Mengatasi kelemahan untuk mengantisipasi ancaman)

$\begin{array}{lrr}\text { a. Melakukan inovasi } & \text { terhadap } \\ \text { pengembangan } & \text { produk } & \text { yang }\end{array}$ mempunyai nilai tambah tinggi dengan harga yang kompetitif

b. Meminimalisasi tingkat kerugian akibat berubahnya harga dan kualitas bahan baku

c. Melakukan kontrol terhadap proses produksi dan pengemasan

d. Melakukan kegiatan pencatatan keuangan agar mempunyai arsip laporan keuangan

SNI menjadi faktor penting dalam penjaminan kualitas atau mutu produk yang dihasilkan, agar lebih kompetitif serta memiliki daya saing di pasaran (Risdianto, 2019). Karena dengan standarisasi ini mampu meyakinkan konsumen bahwa produk tersebut aman, efisien dan baik untuk lingkungan (Prasetyo, 2017). Seiring dengan peningkatan kebutuhan pangan, standar mutu untuk produk pangan menjadi penting (Resnia et a.l, 2016).

Strategi pemasaran mempunyai peran penting bagi UMKM. Peran penting dari strategi pemasaran yang tepat akan mampu meningkatkan daya saing produk yang dihasilkan UKM (Sulistiyani et al., 2020). Pertumbuhan pengguna internet di Indonesia 
terus tumbuh, hal ini merupakan peluang yang harus mampu dimanfaatkan oleh Usaha Kecil Menengah (UKM) sebagai upaya peningkatan daya saing, daya serap dan perluasan pasar. Teknologi Internet dapat digunakan sebagai media pemasaran yang efektif, dengan jangkauan yang sangat luas tidak terbatas oleh ruang dan waktu. Oleh karena itu para pelaku usaha kecil dan menengah harus memanfaatkannya sebagai sarana untuk meningkatkan jangkauan pasar, baik tingkat nasional maupun internasional (Djamaludin et al.,2016).

Sumber daya manusia (SDM) adalah faktor sentral dalam suatu organisasi (Mersita et al., 2019). Strategi untuk peningkatan produktivitas kerja UKM secara keseluruhan fokus utama adalah pekerja dan sistem kerjanya (Meliala et al., 2016). Pengelolaan peningkatan pengetahuan karyawan berpengaruh positif dan signifikan terhadap daya saing UKM (Pitoyo dan Suhartono, 2018). Strategi alternatif meningkatkan daya saing UKM dengan memperhatikan beberapa faktor, prioritas strategi utama meningkatkan produksi (Dhelia et al., 2018). Seiring meningkatnya jumlah produksi hal ini menunjukkan bahwa UKM mampu bersaing dengan produk sejenis.

Menurut Kotler (2011) inovasi produk merupakan setiap barang, jasa atau gagasan yang dianggap sebagai sesuatu yang baru. Sedangkan harga adalah jumlah nilai (kemungkinan ditambah beberapa barang) yang dibutuhkan untuk memperoleh beberapa kombinasi sebuah produk dan pelayanan yang menyertainya (Lamarto, 2006 dalam Al Rasyid \& Indah (2018)). Faktor harga produk selalu menjadi faktor penting dalam proses dalam konteks setiap pembelian pelanggan/konsumen. Konsumen selalu memeriksa informasi harga dan nama merek berbeda ketika mereka membuat penilaian pada ukuran kualitas yaitu: kemudahan penggunaan, kegunaan, kinerja, ketahanan dan status (Rajput et al., 2012).

Al Rasyid \& Indah (2018) menyatakan terdapat pengaruh yang positif dan signifikan antara variabel bebas Inovasi Produk dan
Harga secara bersama-sama terhadap Keputusan Pembelian. Hasil penelitian Susanto (2013) juga menghasilkan bahwa promosi, harga dan inovasi produk berpengaruh secara positif dan signifikan terhadap keputusan pembelian batik tulis Karangmlati Demak.

\section{KESIMPULAN}

Setelah melakukan analisis, maka peneliti berkesimpulan bahwa upaya untuk meningkatkan daya saing UKM keripik nangka di Kabupaten Malang bisa dilakukan dengan beberapa prioritas strategi berikut ini: strategi terbaik untuk menggunakan kekuatan dalam memanfaatkan peluang yang ada adalah; 1) peningkatan kualitas keripik nangka sesuai SNI, karena produk sudah mempunyai kelebihan tidak menggunakan bahan pengawet, 2) memperluas lokasi pemasaran keripik nangka dengan memanfaatkan kemajuan teknologi untuk promosi produk agar penjualan meningkat, 3) meningkatkan keterampilan karyawan dengan melakukan pelatihan yang didampingi oleh lembaga terkait (pemerintah dan lembaga pendidikan), dan 4) meningkatkan jumlah produksi keripik nangka dengan menentukan harga jual yang sesuai dengan kualitas yang dihasilkan dengan melakukan inovasi di setiap proses produksi.

\section{UCAPAN TERIMA KASIH}

Terimakasih disampaikan sebesarbesaranya kepada Kemenristek Dikti dan Universitas Nurul Jadid Probolinggo.

\section{DAFTAR PUSTAKA}

Abdel-Basset, M., Mohamed, M., \& Smarandache, F. (2018). An extension of neutrosophic AHP-SWOT analysis for strategic planning and decisionmaking. Symmetry, 10(4), 116.

Al Rasyid, H., \& Indah, A. T. (2018). Pengaruh Inovasi Produk dan Harga Terhadap Keputusan Pembelian 
Sepeda Motor Yamaha di Kota Tangerang Selatan. Jurnal Perspektif, 16(1), 39-49.

Badan Standardisasi Indonesia. (1996). Standard Nasional Indonesia (SNI) Nomor 01-4296- 1996. Jakarta: Badan Standardisasi Indonesia.

BPS. (2015). Kabupaten Malang dalam angka Tahun 2015. BPS Kabupaten Malang.

Dangayach, G.S., \& Deshmukh, S.G. (2001). Manufacturing strategy, literature review and some issues. International Journal of Operations and Production Management, 21(7), 884-932.

Dhelia, I. A., Oktaviani, R., \& Iskandar, B. H. (2018). Strategi peningkatan daya saing industri bandeng di kabupaten indramayu [increasing competitiveness strategy of milkfish Industry in Indramayu]. Jurnal Ekonomi \& Kebijakan Publik, 9(1), 1-14.

Disperindag (2017). UMKM keripik nangka. Malang

Djamaludin, D., Anwar, A., \& Rukmana, O. (2016). Peningkatan kemampuan usaha kecil menengah di wilayah bandung raya dalam pemanfaaatan internet sebagai sarana pemasaran dan perluasan jangkauan pasar. ETHOS: Jurnal Penelitian dan Pengabdian kepada Masyarakat, 125-130.

Gupta, M. (2015). Strategy formulation for performance improvement of indian corrugated industry: An application of SWOT analysis and QSPM Matrix. Journal of Applied Packaging Research, 7(3), 3.

Gürel, E., \& Tat, M. (2017). SWOT analysis: a theoretical review. Journal of International Social Research, 10(51), 995-1006.

Hermanto, A., Tayibnapis, A. Z., \& Setyaningrum, I. (2016). Strategi pengembangan ukm berbasis inovasi di Provinsi Jawa Timur: Periode 20102014. Jurnal Ekonomi dan Bisnis, 20(2), 93-106.

Holátová, D., \& Monika, B. (2013). Basic characteristics of small and medium- sized enterprises in terms of their goals. International Journal of Business and Social Science, 4(15), 98103.

Hubeis, M., Purwanto, B., Dewi, F. R., Widyastuti, H., \& Febtyanisa, M. (2015). Strategi pengembangan UMKM pangan yang berdaya saing di Indonesia. In Prosiding Seminar Nasional Hasil-Hasil PPM IPB (Vol. 1, pp. 126-143).

Kotler, P. (2011). Manajemen Pemasaran di Indonesia : Analisis, Perencanaan, Implementasi dan Pengendalian. Jakarta : Penerbit Salemba Empat

Kraus S., Kauranen, I., \& Henning, R.C. (2011). Identification of domains for a new conceptual model of strategic entrepreneurship using the configuration approach. Management Research Review, 34(1), 58-74.

Meliala, A. S., Matondang, N., \& Sari, R. M. (2016). Strategi peningkatan daya saing usaha kecil dan menengah (UKM) berbasis Kaizen. Jurnal Optimasi Sistem Industri, 13(2), 641664.

Mersita, D., Fathoni, A., \& Wulan, H. S. (2019). Analysis of empowerment of human resources in efforts to optimize the potential of human capital in umkm (studi pada sentra industri keripik singkong Desa Rambeanak Mungkid Magelang). Journal of Management, 5(5), 1-10.

Muhardi. (2007). Strategi operasi: untuk keunggulan bersaing. Yogyakarta: Graha Ilmu.

Pitoyo, A., \& Suhartono, E.S.E. (2018). Meningkatkan daya saing ukm dari prespektif teknologi informasi, pengelolaan pengetahuan, dan standarisasi produk (studi kasus pada $\mathrm{ukm}$ pengrajin alat peraga/permainan edukatif di klaten).

Prasetyo, P.E. (2017). Standarisasi dan komersialisasi produk industri kreatif dalam mendukung pertumbuhan ekonomi daerah. Prosiding Seminar 
Nasional Multi Disiplin ILMU \& Call for Paper Unisbank ke-3.

Rajput, A. A., Kalhoro, S. H., \& Wasif, R. (2012). Impact of product price and quality on consumer buying behavior: Evidence from Pakistan. Interdisciplinary Journal of Contemporary Research in Business, 4(4), 485-496.

Resnia, R., Wicaksena, B., \& Salim, Z. (2016). Kesesuaian SNI dengan standar internasional dan standar mitra dagang pada produk ekspor perikanan tuna dan cakalang. Jurnal Standardisasi, 17(2), 87-98.

Prianto, F. W. (2011). Pola pengembangan agroindustri yang berdaya saing (Studi kasus Kabupaten Malang). Jurnal Ekonomi Akuntansi dan Manajemen, 10(2), 48-71.

Purwidianti, W., \& Rahayu, T. S. M. (2017). Pengaruh faktor internal dan eksternal terhadap kinerja usaha industri kecil dan menengah di Purwokerto Utara. Kinerja, 19(2), 151-161.

Purwidianti, W., \& Rahayu, T. S. M. (2017). Pengaruh faktor internal dan eksternal terhadap kinerja usaha industri kecil dan menengah di Purwokerto Utara. Kinerja, 19(2), 151-161.

Rangkuti, F. (2015). SWOT balanced scorecard. Jakarta: Gramedia.

Rangkuti, F. (2016). Analisis SWOT: teknik membedah kasus bisnis. Jakarta : Penerbit Gramedia Pustaka Utama.

Rangkuti, F. (2009). Analisis swot teknik membedah kasus bisnis. Jakarta: PT. Gramedia

Resnia, R., Wicaksena, B., \& Salim, Z. (2016). Kesesuaian SNI dengan standar internasional dan standar mitra dagang pada produk ekspor perikanan tuna dan cakalang. Jurnal Standardisasi, 17(2), 87-98.

Risdianto, D. (2019). Penerapan sni mendorong daya saing produk inovasi hasil litbangyasa teknologi keantariksaan. Media Dirgantara, 14(2), 33-35.
Setyoko, A. T. (2019). Identifikasi bahaya dan penentuan titik kendali kritis pada ukm keripik nangka di Jember. Jurnal Standardisasi, 20(3), 171-179.

Solihin, Ismail. 2012. Manajemen Strategik. Jakarta: Penerbit Erlangga

Sucipto, S., Ardiyati, I., \& Effendi, U. (2018). Evaluasi kualitas keripik buah nangka dengan metode six sigma. Jurnal Teknologi Pertanian Andalas, 22(2), 126-138.

Sulistiyani, S., Pratama, A., \& Setiyanto, S. (2020). Analisis Strategi Pemasaran Dalam Upaya Peningkatan Daya Saing Umkm. Jurnal Pemasaran Kompetitif, 3(2), 31-39.

Susanto, A. (2013). Pengaruh promosi, harga dan inovasi produk terhadap keputusan pembelian pada batik tulis karangmlati demak [Doctoral dissertation, Universitas Negeri Semarang].

Thamrin, H., Herlambang, R., Brylian, B., Gumawang, A. K., \& Makmun, A. (2017). A SWOT analysis tool for indonesian small and medium enterprise. ARPN Journal of Engineering and Applied Sciences, 12(2), 620-625.

Wiid, J., Cant, M., \& Holtzhausen, L. (2015). SWOT analysis in the small business sector of South Africa. Corporate Ownership and Control, 13(1), 446-453. 